\title{
Direct costs of occupational asthma due to sensitization in Quebec (1988 to 2002): Revisited
}

\author{
Jean-Luc Malo $\mathrm{MD}^{1}$, Maria-Victoria Zunzunegui $\mathrm{PhD}^{2}$, Jocelyne L'Archevêque $\mathrm{RT}^{1}$, \\ Shélanie Cardinal BSc${ }^{1}$, Heberto Ghezzo PhD ${ }^{1}$
}

\begin{abstract}
J-L Malo, M-V Zunzunegui, J L'Archevêque, S Cardinal, H Ghezzo. Direct costs of occupational asthma due to sensitization in Quebec (1988 to 2002): Revisited. Can Respir J 2011;18(1):e1-e5.
\end{abstract}

BACKGROUND: In a previous study, the authors assessed direct costs for occupational asthma $(\mathrm{OA})$ in a random sample of eight to 10 accepted claims per year for OA between 1988 and 2002. Compensation for loss of income (CLI) was found to be significantly higher for men and for OA caused by low-molecular-weight agents.

OBJECTIVES AND METHODS: To identify sociodemographic factors that modulate CLI, the dossier of each claimant in the previous study was re-examined.

RESULTS: Higher CLI costs were directly related to the duration of CLI (over which loss of income was reimbursed) $(\mathrm{r}=0.65)$. Costs of CLI were higher in patients 30 years of age or older at diagnosis, married subjects and individuals who were offered early retirement or were enrolled in an active interventional rehabilitation program. Higher CLI costs in men, but not in women, were associated with the following sociodemographic factors: older age, different rehabilitation program (early retirement and active program versus no specific program) and married status. Older age was found to be significant in the multivariate analysis performed for men. The cost of CLI was higher in workers with OA caused by low-molecular-weight agents. Although proportionally fewer men and younger workers were affected with OA caused by low-molecular-weight agents, the longer duration of CLI for this category of agent could explain the higher costs.

CONCLUSION: Higher costs for CLI were associated in men (but not women) with older age, married status and type of rehabilitation program (early retirement and active rehabilitation). Higher costs of CLI for OA caused by low-molecular-weight agents were associated with a longer duration of CLI per se, and not with sociodemographic factors.

Key Words: Asthma in the workplace; Compensation; Direct costs

$\mathrm{O}$ cupational asthma (OA) is defined as a type of asthma that is caused by workplace-related factors. The most common form is associated with sensitization to an occupational agent (1). OA and diseases caused by exposure to asbestos dust are currently the most common type of occupational respiratory diseases (2). The socioeconomic aspects of OA have not been examined to the same extent as clinical and epidemiological issues (3). Individuals with possible $\mathrm{OA}$ were more likely to be less educated according to findings in a Brazilian study (4), and took more time to submit a claim if they had a lower annual income, as found in a study conducted in Ontario (5).

Recently, we published data on the direct cost of OA to the Québec medicolegal agency, the Commission de la santé et sécurité du travail du Québec (CCST) (6). This study included a random sample of eight to 10 cases of OA per year accepted by the CSST for the 15-year period from 1988 to 2002 . The following information was obtained: cost for compensation due to loss of income (CLI) - the income representing the salary at the time of diagnosis and the CLI representing the difference between the current salary and the salary at the time of diagnosis that was reimbursed; cost of compensation due to functional impairment (CFI) allocated two years after diagnosis; total costs (ie, CLI + CFI costs); sex and age; region of Quebec (Quebec City,

\author{
Une revue des coûts directs de l'asthme \\ professionnel causé par la sensibilisation au \\ Québec (1988 à 2002)
}

HISTORIQUE : Dans une étude antérieure, les auteurs ont évalué les coûts directs de l'asthme professionnel (AP) dans un échantillon aléatoire de huit à dix réclamations d'AP acceptées par année entre 1988 et 2002. Il a été constaté que l'indemnisation pour perte de revenu (IPR) était considérablement plus élevée pour les hommes et pour l'AP causé par des agents de faible masse moléculaire. OBJECTIFS ET MÉTHODOLOGIE : Pour déterminer les facteurs sociodémographiques qui modulent l'IPR, les chercheurs ont de nouveau examiné le dossier de chaque requérant, de l'étude précédente.

RÉSULTATS : Les coûts plus élevés de l'IPR étaient directement proportionnels à la période de l'IPR (au cours de laquelle la perte de revenu a été remboursée) $(\mathrm{r}=0,65)$. Les coûts de l'IPR étaient plus élevés chez les patients de 30 ans ou plus au diagnostic, chez les sujets mariés et chez les personnes à qui on avait proposé une retraite anticipée ou qui participaient à un programme actif de réadaptation professionnelle. Les coûts plus élevés de l'IPR chez les hommes, mais pas chez les femmes, s'associaient aux facteurs sociodémographiques suivants : âge plus avancé, programme de réadaptation différent (retraite anticipée et programme actif par rapport à l'absence de programme précis) et état matrimonial. L'âge plus avancé était perçu comme significatif dans l'analyse multivariée effectuée pour les hommes. Le coût de l'IPR était plus élevé chez les travailleurs atteints d'AP causé par des agents de faible masse moléculaire. Même si, proportionnellement, moins d'hommes et de jeunes travailleurs étaient touchés par l'AP causé par des agents de faible masse moléculaire, la plus longue période d'IPR pour cette catégorie d'agent pourrait expliquer les coûts plus élevés.

CONCLUSION : Les coûts plus élevés de l'IPR s'associaient aux hommes (et non aux femmes), à un âge plus avancé, à l'état matrimonial et au type de programme de réadaptation (retraite anticipée et réadaptation active). Les coûts plus élevés de l'IPR pour l'AP causé par des agents de faible poids moléculaire s'associaient à une plus longue durée d'IPR en soi, et non à des facteurs sociodémographiques.

Montreal or other); type of causal agent (categorized as high- or lowmolecular weight); use of inhaled steroids to control asthma at the time of diagnosis and two years later (ie, at the time of reassessment of functional impairment); airway calibre and responsiveness to methacholine; and type of rehabilitation that was offered, which was separated into the following five categories: return to work for the same employer in a different job capacity with no exposure to the causal agent; work for a different employer without a retraining program; work for a different employer with a training program; retired; or unemployment. We showed that the median costs were $\$ 40,700$, $\$ 7,600$ and $\$ 61,300$, respectively for CLI, CFI and total, respectively, for the period between 1988 and 2002. We also showed that median CLI costs were significantly higher in men than in women $(\$ 70,000$ versus $\$ 13,000$, respectively), workers 40 years of age and older versus those younger than 40 years of age $(\$ 90,000$ versus $\$ 27,000$, respectively), with $\mathrm{OA}$ due to low- versus high-molecular-weight agents ( $\$ 51,000$ versus $\$ 38,000$, respectively) and taking inhaled steroids both at diagnosis $(\$ 92,000$ versus $\$ 52,000)$ and reassessment $(\$ 81,000$ versus $\$ 35,000)$, respectively. The median CFI costs were also higher in patients who required retraining and those who accepted early retirement than in workers who stayed with the same employer but in a

${ }^{1}$ Axe de recherche en santé respiratoire, Hôpital du Sacré-Coeur de Montréal; ${ }^{2}$ Département de médecine sociale et préventive, Université de

Montréal, Montréal, Québec

Correspondence: Dr Jean-Luc Malo, Department of Chest Medicine, Hôpital du Sacré-Coeur de Montréal, 5400 West Gouin Boulevard,

Montréal, Québec H4J 1C5. Telephone 514-338-2796, fax 514-338-3123, e-mail maloj@meddir.umontreal.ca 
TABLE 1

Baseline characteristics

\begin{tabular}{|c|c|c|c|}
\hline Characteristic & $\begin{array}{c}\text { Total } \\
(n=140)\end{array}$ & $\begin{array}{c}\text { Women } \\
(n=39[28 \%])\end{array}$ & $\begin{array}{c}\text { Men } \\
(n=101[72 \%])\end{array}$ \\
\hline Age at diagnosis, years & $40.7 \pm 12.2$ & $36.6 \pm 11.8$ & $42.3 \pm 12.0$ \\
\hline$<30$ & $31(22)$ & $13(33)$ & $18(18)$ \\
\hline$<40$ & $66(47)$ & $22(56)$ & $42(42)$ \\
\hline$<55$ & $107(76)$ & $34(87)$ & $73(72)$ \\
\hline Atopy ${ }^{\star}, \mathrm{n} / \mathrm{n}(\%)$ & $79 / 123(64)$ & $27 / 35(77)$ & $52 / 88(59)$ \\
\hline \multicolumn{4}{|l|}{ Causal agent } \\
\hline High molecular weight & $61(44)$ & $23(59)$ & $38(38)$ \\
\hline Low molecular weight & $62(44)$ & $11(28)$ & $51(51)$ \\
\hline Unknown & $17(12)$ & $5(13)$ & $12(12)$ \\
\hline $\mathrm{FEV}_{1}, \%$ predicted (mean $\pm \mathrm{SD}$ ) & $86.3 \pm 18.5$ & $87.4 \pm 18.3$ & $85.9 \pm 18.6$ \\
\hline $\mathrm{n}<80 \%$ predicted & 45/138 (33) & 10/37 (27) & $35(35)$ \\
\hline $\mathrm{FEV}_{1} / \mathrm{FVC}, \%($ mean $\pm \mathrm{SD})$ & $71.9 \pm 10.8$ & $76.3 \pm 10.2$ & $70.2 \pm 10.6$ \\
\hline $\mathrm{n}<70 \%$ & $51 / 136(38)$ & $8 / 37(22)$ & 43/99 (43) \\
\hline $\mathrm{PC}_{20}<16 \mathrm{mg} / \mathrm{mL}$ & $119(85)$ & $31(80)$ & $88(87)$ \\
\hline $\begin{array}{l}\text { Annual salary at the time of } \\
\text { diagnosis }^{\dagger}(\text { mean } \pm S D)\end{array}$ & $26.7 \pm 13.1$ & $17.9 \pm 6.8$ & $28.6 \pm 13.4$ \\
\hline \multicolumn{4}{|l|}{ Level of education } \\
\hline Primary/secondary & $40(29)$ & $9(23)$ & $31(31)$ \\
\hline College/university & $30(21)$ & $15(38)$ & $15(15)$ \\
\hline Missing information & $70(50)$ & $15(38)$ & $55(55)$ \\
\hline \multicolumn{4}{|l|}{ Marital status } \\
\hline Married & $63(45)$ & $11(28)$ & $52(52)$ \\
\hline Single & $41(29)$ & $15(39)$ & $26(26)$ \\
\hline Other & $5(4)$ & $2(5)$ & $3(3)$ \\
\hline Unknown & $31(22)$ & $11(28)$ & $20(20)$ \\
\hline \multicolumn{4}{|l|}{ Rehabilitation program ${ }^{\ddagger}$} \\
\hline Present & $49(35)$ & $14(36)$ & $35(35)$ \\
\hline Absent & $45(32)$ & $15(38)$ & $30(30)$ \\
\hline Early retirement & $24(17)$ & $2(5)$ & $22(22)$ \\
\hline Unknown & $22(16)$ & $8(21)$ & $14(14)$ \\
\hline
\end{tabular}

Data presented as $n(\%)$ unless otherwise indicated. ${ }^{*}$ Atopy defined as at least one immediate skin reaction to a panel of 15 common aeroallergens; ${ }^{\dagger} \times \$ 1,000$; ${ }^{\ddagger}$ The Commission de la santé et sécurité du travail du Québec offered a rehabilitation program if it was required for finding another job. FEV 1 Forced expiratory volume in $1 \mathrm{~s}$; FVC Forced vital capacity; $P C_{20}$ Provocative concentration of methacholine causing a 20\% decrease in FEV ${ }_{1}$

different job capacity. Median CFI costs were significantly higher for those treated with inhaled steroids at the time of diagnosis and reassessment, and those left with bronchial hyper-responsiveness.

While it is readily understandable for CLI costs to be higher for older workers who are offered early retirement (after 55 years of age), and for CLI and CFI costs to be more important in those taking inhaled steroids at the time of diagnosis and reassessment, the reasons for higher costs in men and in the case of OA caused by low-molecular-weight agents are not clear. Whereas men may earn higher salaries (CLI represents the difference in salary at the time of diagnosis and at follow-up), which can explain higher CLI and total costs, other sociodemographic variables such as age at diagnosis, level of education, marital status or type of rehabilitation program offered can intervene. Moreover, these variables may play different roles in men and in women. Therefore, we attempted to determine whether socioeconomic variables such as age at diagnosis, level of education, marital status and type of rehabilitation program, which were examined separately in men and in women and according to the type of causal agent, contributed to costs.

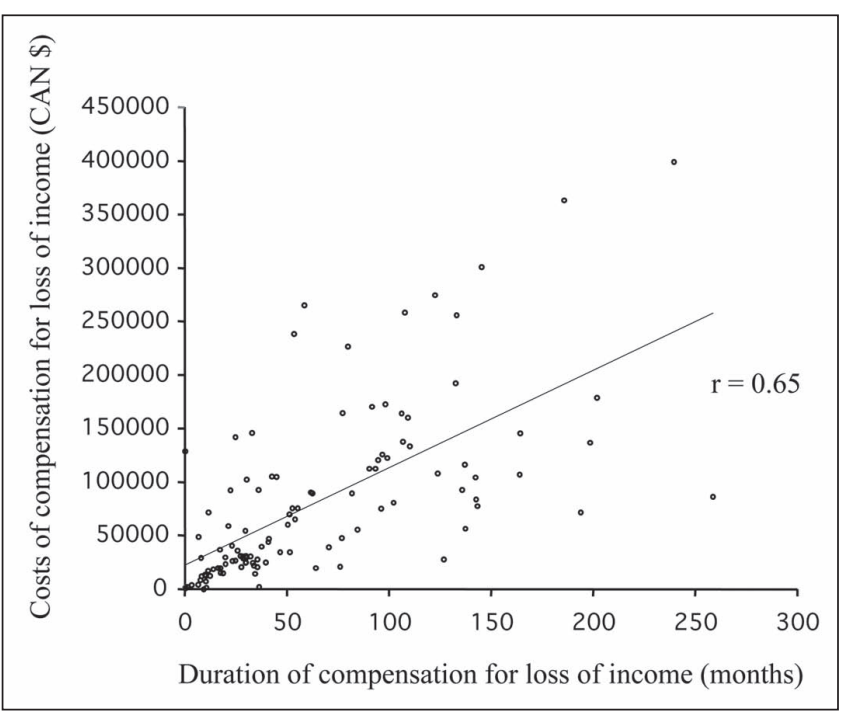

Figure 1) Relationship between duration of compensation for loss of income and costs of compensation for loss of income. The regression line is shown, as is the regression coefficient, which was highly significant $(P<0.001)$

\section{Patients}

\section{METHODS}

In the previous study (6), eight to 10 subjects per year from a random sample of 140 workers with OA accepted by the CSST between 1998 and 2002, were examined. Detailed dossiers for each of these claimants (ie, the same workers as in the initial study) were available and contained information regarding duration of CLI, level of education, marital status and type of rehabilitation program (retraining, job with the same or a different employer without retraining, or retired). This information was not available for all variables because it had not been systematically collected. It resulted from an open-frame interview conducted by a CSST employee and was retrospectively examined.

All of this information was provided confidentially by the CSST. The project was approved by the Research Ethics Committee of Hôpital du Sacré-Cœur de Montréal (Montréal, Québec). Parametric or nonparametric tests were used according to the distribution of data examined by univariate and multivariate analyses. Statistical analysis was performed using SPSS version 16 (IBM Corporation, USA).

\section{RESULTS}

The present study included eight to 10 subjects per year from a group of 140 randomly selected patients, the majority of whom were men, over a 15-year period (1988 to 2002). Table 1 summarizes baseline characteristics for all patients and for men and women separately. The mean age of the sampled group was 40 years. Approximately one-third of the patients showed significant airway obstruction at the time of diagnosis, with the vast majority experiencing bronchial hyperresponsiveness when they were initially assessed. Generally, information in the CSST dossiers regarding socioeconomic variables was available, except for education level, in which only $50 \%$ of the files contained sufficient data. Causal agents were evenly divided between high- and low-molecular-weight types. The majority of subjects were married. In $35 \%$ of the subjects, the CSST actively intervened in rehabilitation programs designed to help the worker find another job.

The principal cost was related to the allocation of the CLI, which corresponded to nearly two-thirds of the total cost. Because the cost of this allocation is directly related to its duration (Figure 1), the duration of this allocation according to socioeconomic variables was also examined (Table 2). Costs of CLI were significantly higher and duration of allocation was significantly longer for men. Costs of CLI were also 
TABLE 2

Costs and duration of compensation for loss of income according to socioeconomic factors

\begin{tabular}{|c|c|c|c|c|c|c|}
\hline & $\mathrm{n}$ & $\begin{array}{c}\text { Cost, } \times \$ 1,000 \\
\text { median (Q1-Q3)* }\end{array}$ & $\mathbf{P}$ & $\mathrm{n}$ & $\begin{array}{l}\text { Duration, months, } \\
\text { median (Q1-Q3)* }\end{array}$ & $\mathbf{P}$ \\
\hline \multicolumn{7}{|l|}{$\overline{\text { Sex }}$} \\
\hline Men & 94 & $62(19-123)$ & & 79 & $54.1(23.3-106.7)$ & \\
\hline \multicolumn{7}{|l|}{ Age at diagnosis, years } \\
\hline$<30$ & 29 & $28(19-52)$ & & 25 & $34.0(26.2-49.8)$ & \\
\hline$\geq 30$ & 101 & $56(19-124)$ & 0.04 & 86 & $52.6(21.1-107)$ & 0.15 \\
\hline$\geq 40$ & 66 & $82(20-143)$ & 0.003 & 56 & $62.3(22.9-108.8)$ & 0.09 \\
\hline$<55$ & 107 & $31(15-77)$ & & 88 & $35.7(21.4-81.5)$ & \\
\hline$\geq 55$ & 23 & $121(89-173)$ & $<0.001$ & 23 & $98.2(44.9-122.5)$ & 0.02 \\
\hline \multicolumn{7}{|l|}{ Causal agent } \\
\hline High molecular weight & 64 & $26(9-76)$ & & 54 & $33.4(13.0-80.5)$ & \\
\hline Low molecular weight & 61 & $54(29-133)$ & 0.001 & 52 & $52.6(29.8-107.7)$ & 0.01 \\
\hline \multicolumn{7}{|l|}{ Marital status } \\
\hline Married & 59 & $77(19-145)$ & & 51 & $61.9(29.7-110.3)$ & \\
\hline Single & 44 & $31(21-56)$ & 0.003 & 38 & $32.8(20.9-57.2)$ & 0.02 \\
\hline Rehabilitation & Absent $^{\dagger}$ & Present $^{\dagger}$ & Retired $^{\dagger}$ & Absent $^{\ddagger}$ & Present $^{\ddagger}$ & Retired $^{\ddagger}$ \\
\hline $\mathrm{n}$ & 40 & 48 & 23 & 27 & 47 & 22 \\
\hline Median & 25 & 42 & 120 & 34.3 & 37.6 & 95.7 \\
\hline Q1-Q3* & $(1.3-56)$ & $(24-90)$ & $(90-170)$ & $(17.6-106.7)$ & $(25.8-77.4)$ & $(59.3-122.9)$ \\
\hline
\end{tabular}

${ }^{*} Q 1-Q 3$ values represent the first and third quartiles of distribution; ${ }^{\dagger}$ Comparisons: Absent versus present $(P=0.006)$, present versus retired (P<0.001) and absent versus retired $(P<0.001)$; ${ }^{\ddagger}$ Comparisons: Absent versus present $(P=0.8)$, present versus retired $(P=0.008)$ and absent versus retired $(P=0.04)$.

higher in workers 30 years of age and older, more so in those 40 years of age and older, and 55 years of age and older, as well as in those with only a primary or secondary level of education. Costs and duration of allocation for CLI were significantly longer in married versus single subjects. Costs and duration of allocation for CLI were also significantly longer in workers who were offered early retirement. There were no significant differences in the cost and duration of CLI in workers who were employed by a company of 20 employees or more at the time of diagnosis (versus those who were not) or had been with the same employer for five years or longer (versus those who had not) (data not shown).

The mean $( \pm \mathrm{SD})$ age at diagnosis was significantly higher in men than in women $(42.3 \pm 12.0$ years versus $36.6 \pm 11.8$ years, respectively; $\mathrm{P}=0.01$ ) (Table 1). As shown in Table 3 , higher costs in men were associated with older age (30, 40 and 55 years of age and older versus younger than 30,40 and 55 years of age, respectively), agents with a low- versus high-molecular weight and married status versus not married status. These factors were not different in women, although there was a borderline significance for higher costs in women with a primary/ secondary level of education. In the multivariate analysis performed in men that incorporated age at diagnosis (younger than 30 years versus 30 years of age or older), type of causal agent (high versus low molecular weight) and active rehabilitation program (present versus absent), only older age at diagnosis remained significant $(\mathrm{P}=0.02)$.

Determining whether socioeconomic variables were different in workers with OA caused by high- versus low-molecular-weight agents was also of interest. The duration of CLI was significantly longer for workers with $\mathrm{OA}$ caused by low-molecular-weight agents (median 51.6 months, interquartile range 29.7 to 107.7 months, $\mathrm{P}=0.02$ ) than workers with $\mathrm{OA}$ caused by high-molecular-weight agents (median 35.6 months, interquartile range 12.5 to 83.3 months). As shown in Table 4, proportionally more men were affected with OA caused by high-molecular-weight agents. Furthermore, the diagnosis of $\mathrm{OA}$ was made at an older age for this type of agent. There were no significant differences in the level of education or rehabilitation program for high-and low-molecular-weight agents for all subjects and, after examining data stratified according to sex, the only significant difference was that proportionally more women with OA caused by lowmolecular-weight agents were married.

\section{DISCUSSION}

In a previous study (6), we found that the severity of asthma influenced the costs of CLI, with median costs at diagnosis and reassessment of OA two years after diagnosis in those on inhaled steroids of $\$ 92,000$ and $\$ 81,000$, respectively, compared with $\$ 58,000$ and $\$ 35,000$, respectively, in other subjects. Aside from the influence of asthma severity on costs, sociodemographic factors also play a role. The current study showed that the direct costs and duration of CLI were higher and longer in men than in women (Table 2). Men with higher costs were older at diagnosis, had different marital status (married) and rehabilitation (early retirement and active rehabilitation program offered) than men with lower costs, and likely a lower level of education; however, for the latter variable, there were insufficient data to draw firm conclusions.

Socioeconomic factors have not been sufficiently examined as conditioners of delay in diagnosis, the principal determinant of persisting asthma after removal from exposure and outcome of OA (3). Caldeira et al (4) showed that in Sao Paulo, Brazil, possible OA was more prevalent in subjects with lower education levels. In a study performed in Ontario, Poonai et al (5) found that the delay in consulting a physician was longer in workers with a lower level of education and salary. Delays in referral are influenced by socioeconomic factors, as shown in a recent study by our group (7). In this prospective study of 60 workers with OA, we found that being older, having an income of greater than $\$ 30,000$ per year and having OA caused by highmolecular-weight agent(s) were all positively associated with the number of years of exposure with symptoms before removal from exposure. In Belgium, the risk of remaining unemployed or having to change 
TABLE 3

Costs for loss of income according to socioeconomic factors in men and women

\begin{tabular}{|c|c|c|c|c|c|c|}
\hline \multirow[b]{2}{*}{ Socioeconomic factor } & \multicolumn{3}{|c|}{ Men } & \multicolumn{3}{|c|}{ Women } \\
\hline & $\mathbf{n}$ & $\begin{array}{l}\text { Cost, } \times \$ 1,000 \\
\text { median }(\mathrm{Q} 1-\mathrm{Q} 3)^{*}\end{array}$ & $\mathbf{P}$ & $\mathbf{n}$ & $\begin{array}{l}\text { Cost, } \times \$ 1,000 \\
\text { median }(\mathrm{Q} 1-\mathrm{Q} 3)^{*}\end{array}$ & $\mathbf{P}$ \\
\hline \multicolumn{7}{|l|}{ Age at diagnosis, years } \\
\hline$\geq 30$ & 76 & $87(20-143)$ & 0.03 & 25 & $25(12-58)$ & 1.0 \\
\hline$<40$ & 42 & $40(16-88)$ & & 22 & $26(17-34)$ & \\
\hline$\geq 40$ & 52 & $97(29-164)$ & 0.004 & 14 & $25(9-76)$ & 0.8 \\
\hline$\geq 55$ & 21 & $123(91-183)$ & $<0.001$ & 2 & & \\
\hline \multicolumn{7}{|l|}{ Causal agent } \\
\hline High molecular weight & 34 & $48(6-96)$ & & 20 & $22(19-31)$ & \\
\hline Low molecular weight & 49 & $90(35-153)$ & 0.03 & 11 & $25(4-52)$ & 1.0 \\
\hline \multicolumn{7}{|l|}{ Level of education } \\
\hline Primary/secondary & 28 & $98(25-128)$ & & 8 & $52(16-79)$ & \\
\hline Rehabilitation & Absent $^{\dagger}$ & Present $^{\dagger}$ & Retired $^{\dagger}$ & Absent $^{\ddagger}$ & Present $^{\ddagger}$ & Retired \\
\hline$n$ & 27 & 35 & 21 & 13 & 13 & 2 \\
\hline Median & 16 & 59 & 123 & 25 & 25 & 55 \\
\hline Q1-Q3* & $(1.1-76)$ & $(31-107)$ & $(98-171)$ & $(10-43)$ & $(20-37)$ & - \\
\hline
\end{tabular}

${ }^{*} Q 1-Q 3$ values represent the first and third quartiles of distribution; ${ }^{\dagger}$ Comparisons: Absent versus present $(P<0.001)$, present versus retired ( $\left.P=0.001\right)$ and absent versus retired $(P=0.006) ;{ }^{\ddagger}$ Comparison of absent versus present not statistically significant

TABLE 4

Relationship between molecular weight of the agent causing occupational asthma (OA) and socioeconomic outcomes

\begin{tabular}{|c|c|c|c|c|c|c|c|c|c|}
\hline Sex, n (\%) & \multicolumn{4}{|c|}{ OA caused by high-molecular-weight (HMW) agent } & \multicolumn{4}{|c|}{ OA caused by low-molecular-weight (LMW) agent } & $\begin{array}{c}\mathbf{P} \\
0.01\end{array}$ \\
\hline Male & \multicolumn{4}{|c|}{$51(82)$} & \multicolumn{4}{|c|}{$38(62)$} & \\
\hline \multirow[t]{3}{*}{ Female } & \multicolumn{4}{|c|}{$11(18)$} & \multicolumn{4}{|c|}{$23(38)$} & \\
\hline & \multicolumn{3}{|c|}{ Total } & \multicolumn{3}{|c|}{ Men } & \multicolumn{3}{|c|}{ Women } \\
\hline & HMW & LMW & $\mathbf{P}$ & HMW & LMW & $\mathbf{P}$ & HMW & LMW & $\mathbf{P}$ \\
\hline $\begin{array}{l}\text { Age at diagnosis, years, } \\
\text { median (Q1-Q3)* }\end{array}$ & $\begin{array}{c}41.5 \\
(28-47.5)\end{array}$ & $\begin{array}{c}36.0 \\
(28-47.5)\end{array}$ & 0.03 & $\begin{array}{c}44.0 \\
(37-57)\end{array}$ & $\begin{array}{c}37.0 \\
(31-50.5)\end{array}$ & 0.07 & $\begin{array}{c}33.0 \\
(23-46)\end{array}$ & $\begin{array}{c}33.0 \\
(26-45)\end{array}$ & 0.8 \\
\hline \multicolumn{10}{|l|}{ Level of education } \\
\hline Primary/secondary & $19(53)$ & $17(41)$ & & $17(71)$ & $11(65)$ & & $2(33)$ & $6(38)$ & \\
\hline College/university & $11(47)$ & $16(59)$ & 0.25 & 7 (29) & $6(35)$ & 0.5 & $4(67)$ & $10(63)$ & 0.6 \\
\hline \multicolumn{10}{|l|}{ Marital status } \\
\hline Married & $27(51)$ & $26(51)$ & & 27 (68) & $17(57)$ & & $0(0)$ & $9(56)$ & \\
\hline Single & $21(49)$ & 20 (49) & 0.6 & $13(32)$ & $13(43)$ & 0.25 & $8(100)$ & $7(44)$ & 0.009 \\
\hline \multicolumn{10}{|l|}{ Rehabilitation } \\
\hline Absent & $17(30)$ & $22(45)$ & & $14(30)$ & $13(41)$ & & $3(30)$ & $9(53)$ & \\
\hline Present & $16(29)$ & $7(14)$ & & $15(32)$ & $7(22)$ & & $1(10)$ & $0(0)$ & \\
\hline Retired & $24(42)$ & $20(41)$ & 0.14 & $18(38)$ & $12(37)$ & 0.5 & $6(60)$ & $8(47)$ & 0.3 \\
\hline
\end{tabular}

Data presented as $n(\%)$ unless otherwise indicated. ${ }^{*} Q 1-Q 3$ values represent the first and third quartiles of distribution

employers was also associated with older age in workers with OA (8). However, in France, the opposite was found, possibly because retraining programs are not readily offered to young workers affected with OA (9). Marabini et al (10) also showed that workers with OA and dependent family members were more likely to continue working. A low education level was identified as a predictor of unemployment after a diagnosis of $\mathrm{OA}(9,10)$.

In the current study, we showed that costs and duration of CLI, which is directly related to costs of CLI and accounts for the largest portion of the direct cost, are related to socioeconomic factors in men. Whereas finding a new job is clearly more difficult in older subjects and those of lower education level, it is not clear why married men had higher costs and longer CLI periods. We hypothesize that living with another employed person makes the need for returning to work less urgent.

Our study examined a 15-year period (1988 to 2002), which significantly reduced the possible confounding effects of short-term economic cycles. Therefore, we believe that the socioeconomic factors related to the duration of CLI play a role regardless of the economic situation. However, these variables may differ greatly from one region to another. Therefore, performing similar studies in different Canadian provinces and other countries is warranted, particularly because the compensation system for $\mathrm{OA}$ varies greatly from region to region. Moreover, the Quebec situation warrants re-examination at regular intervals because of possible changes in the rehabilitation programs offered by the CSST. 
Costs for and duration of CLI as shown in the present study were significantly longer for men (but not women) with OA caused by low-molecular-weight agents (Tables 2 and 3). The fact that proportionally more men and older individuals had OA caused by high-molecular-weight agents (Table 4) contradicts the hypothesis that these factors had played a role. Therefore, it is likely that social variables were not principal conditioners of these differences in costs that were, therefore, principally related to the duration of CLI per se. Diisocyanates, particularly hexamethylene-diisocyanate, were the principal lowmolecular-weight agents that caused OA. Workers with OA caused by hexamethylene-diisocyanate generally work in small autobody shops; therefore, re-assigning these workers to a different location in the same workplace is usually not possible. These workers need to be retrained for a new job which, consequently, results in longer CLI.

Our study has limitations. The information was collected in a nonsystematic manner because our study was retrospective in nature. Many dossiers were incomplete, particularly for data regarding education level - a piece of information that was unavailable for one-half of

\section{REFERENCES}

1. Bernstein IL, Chan-Yeung M, Malo JL, Bernstein DI.

Definition and classification of asthma in the workplace. In: Asthma in the Workplace, 3rd edn. Bernstein IL, Chan-Yeung M,

Malo JL, Bernstein DI, eds. New York: Taylor \& Francis, 2006:1-8.

2. Becklake M, Chan-Yeung M, Malo JL. Epidemiological approaches in occupational asthma. In: Asthma in the Workplace, 3rd edn. Bernstein IL, Chan-Yeung M, Malo JL, Bernstein DI, eds. New York: Taylor \& Francis, 2006:37-85.

3. Malo JL, Lemière C, Gautrin D, Labrecque $M$, Lavoie K. Asthma and the workplace. In: Asthma, Health, and Society. Harver A, Kotses H, eds. New York: Springer, 2010:303-23.

4. Caldeira RD, Bettiol H, Barbieri MA, Terra-Filho J, Garcia CA, Vianna EO. Prevalence and risk factors for work related asthma in young adults. Occup Env Med 2006;63:694-9.

5. Poonai N, Diepen S, Bharatha A, Manduch M, Deklaj T, Tarlo SM. Barriers to diagnosis of occupational asthma in Ontario.

Can J Public Health 2005;96:230-3. the subjects. In addition, the lack of association between sociodemographic variables and costs of $\mathrm{OA}$ in women could be explained by the small number of women in the sample.

Acknowledging the relationships between socioeconomic variables and costs, compensation agencies and public health authorities should target these factors in surveillance programs, especially in men. Identifying these workers may reduce the delay in diagnosis and result in more effective retraining opportunites offered to younger individuals.

ACKNOWLEDGEMENTS: The authors thank the Québec CSST for kindly providing research data, and Mrs Kathe Lieber for reviewing the manuscript.

FUNDING: Center for Asthma in the Workplace, Centre LéaRobback sur les inégalités sociales de la santé, Canadian Institutes of Health Research, no. CDA 66154.

6. Malo JL, L'Archevêque H, Ghezzo H. Direct costs of occupational asthma in Quebec between 1988 and 2002. Can Respir J 2008;15:413-6.

7. Miedinger D, Malo JL, Ghezzo H, L'Archevêque J, Zunzunegui MV. Factors influencing duration of exposure with symptoms and costs of occupational asthma. Eur Respir J 2010;36:728-34.

8. Larbanois A, Jamart J, Delwiche JP, Vandenplas O.

Socioeconomic outcome of subjects experiencing asthma symptoms at work. Eur Respir J 2002;19:1107-13.

9. Ameille J, Descatha A. Outcome of occupational asthma. Curr Opin Allergy Clin Immunol 2005;5:125-8.

10. Marabini A, Ward H, Kwan S, Kennedy S, Wexler-Morrison N, Chan-Yeung M. Clinical and socioeconomical features of subjects with red cedar asthma - a follow up study. Chest 1993;104:821-4. 


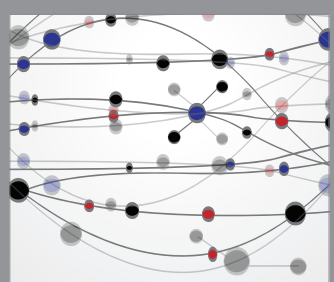

The Scientific World Journal
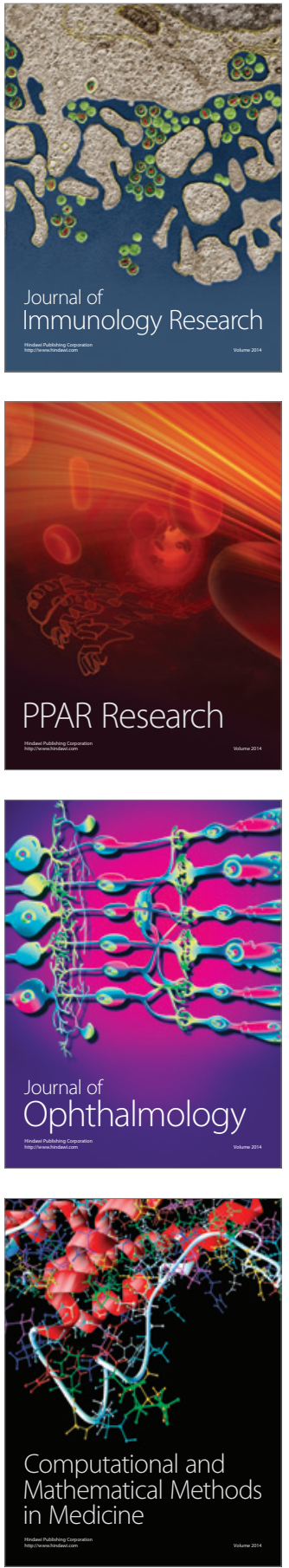

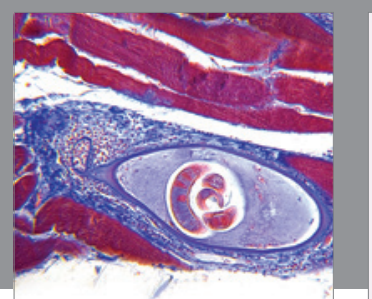

Gastroenterology Research and Practice

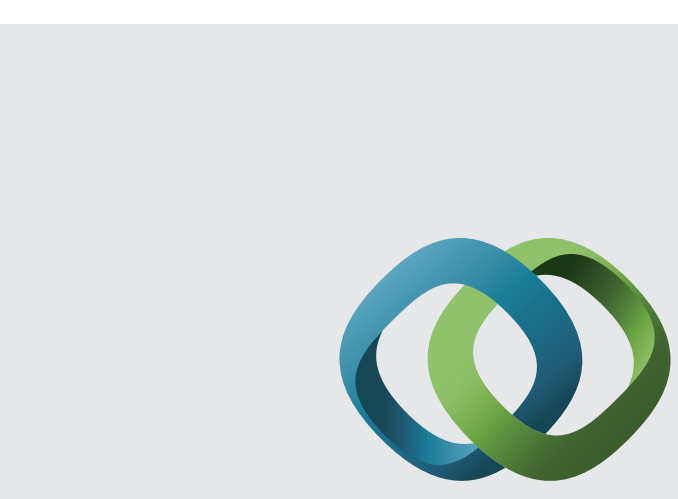

\section{Hindawi}

Submit your manuscripts at

http://www.hindawi.com
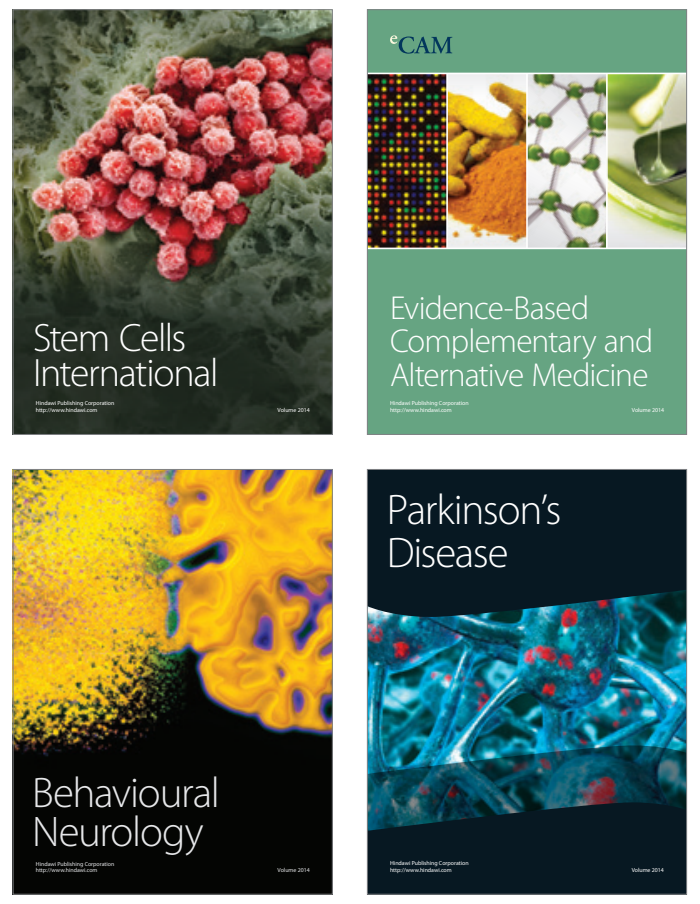
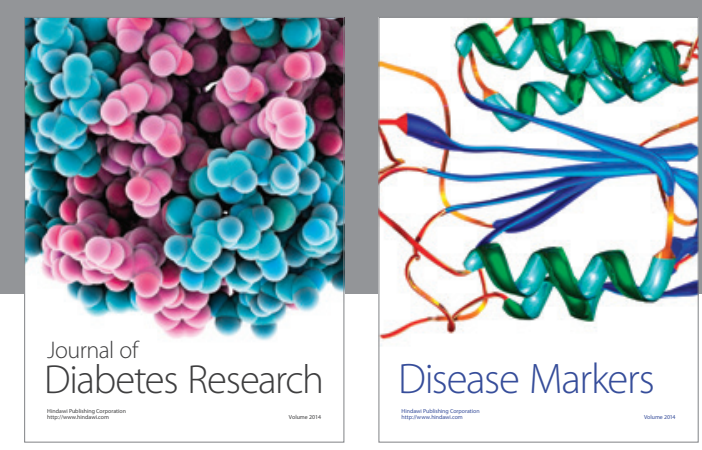

Disease Markers
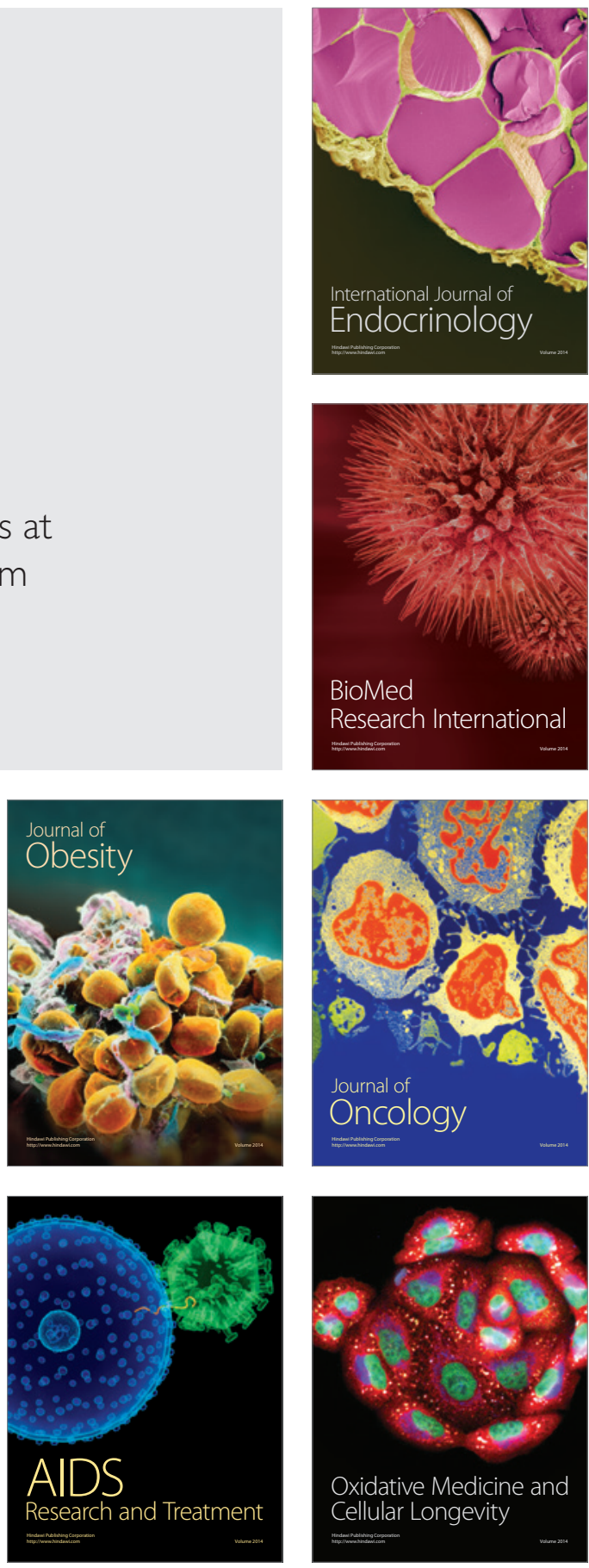